\title{
Participation of indigenous and rural people in the construction of developmental and environmental public policies in Mexico.
}

\author{
Luisa Paré and Carlos Robles, with Carlos Cortes.
}

\section{Introduction and background}

Mexico today is in a process of political transition and entry into a new phase of market globalisation, as exemplified by international trade agreements with North America (NAFTA), the European Union, and the Central American System of Economic Integration (SICA). At the same time, the temporarily restored dialogue with the Zapatista armed indigenous movement in early 2001 triggered renewed interest in the potential for cultural and biological sustainability in the region. The Zapatistas demand respect for cultural and ethnic diversity and territorial autonomy, the fulfilment of which could be highly beneficial for the conservation of the biological wealth of the lands of the indigenous and peasant societies located in south-east Mexico, and for the preservation of cultural identities.

This article seeks to contribute some theoretical elements to this conflict, and to the analysis of the use and management of natural resources in the context of wider debates about development. In order to pursue these discussions, three key questions have been identified, around which this article is structured. Firstly, given that there are different conceptualisations of the appropriation of nature - those who pursue the individual versus those based on social appropriation of nature - which prevails and why? Here we also consider how these different conceptualisations are rooted in different development paradigms. Secondly, and as a consequence of these differing approaches to the appropriation of nature, there are also differing paths or approaches to participation. Whose voices are heard in the debates about the use of natural resources, and about development models? What are the mechanisms through which excluded groups (such as the indigenous peoples of Mexico) can make their views known? Thirdly, we try to draw together theoretical debates around the appropriation of nature and approaches to participation and inclusion, to build some potential links between participation and sustainable development. This involves analysis of the ways in which emerging initiatives for sustainable development are articulated, together with their potential for redesigning environmental policy.

The south-east region of Mexico i particularly rich in natural resources of highly strategic interest, especially for biodiversity. The strategic importance of these resources situates the region as an enclave in a new geo-economic integration pushed forward by national and multinational corporations, multilateral organizations and the federal government. These resources have traditionally been managed by local indigenous communities, and the Zapatista's demands for continued local control contest some aspects of the international economic agreements that the Mexican 
government is in the process of negotiating, in particular, the 'Plan Puebla-Panamá (PPP)'. The PPP has sparked a nation-wide debate around the concept of sovereignty over resources, and concerns about how the culture, traditional organisation and territory of millions of inhabitants of the region would be affected.

Previously a sub-component of regional proposals for economic and structural development, the PPP is now promoted by Fox's administration as a new, international sustainable and holistic development project, aimed at improving the livelihoods of poor people in the south-east region and creating employment, reducing north-south inequities in Mexico. However, according to its critics, the aim of the PPP is to open alternative routes to the Panama Canal for international trade, to facilitate appropriation by multinational capital of energy, water and biodiversity resources. Further they argue, it seeks to capitalise on the low cost of labour in the region and to create a barrier to stem the flow of migrants from Central America towards the United Statesi.

The PPP has generated concern and mobilisation of indigenous people and peasants, which has been taken up by the EZLN (Zapatista National Liberation Army) and the National Indigenous Congress (CNI). They demand fulfilment of Convention 169 of the UN International Labour Organisation signed by the Mexican government to guarantee inclusion of indigenous peoples in designing their own development processes. Since 1994, the government's response to the Zapatistas has passed through several stages, from military intervention to dialogue. With the new regime of President Fox in 2001, a national mobilisation of the Zapatista movement was successful in bringing discussion of the Law of Concord and Pacification (Cocopa) to Congress. Although the former President Zedillo had commissioned the Cocopa Law in order to reach some kind of agreement with the Zapatistas, he himself rejected it. When the same law was presented to the new Congress, it was rejected again and replaced with another proposal, which the Zapatistas in turn rejected. One of the main points of controversy was to do with control over territory and natural resources. The formal proposal provides for the collective use of both natural resources and territory, while the law approved by the Congress omits this provision for collective management and refers only to the modalities of land tenure established in the Constitution. It emphasises the rights of third parties to preferential use of the natural resources in those spaces inhabited by communities.

Despite repeated marches and dialogues with Congress where different legislative proposals have been under debate, the Zapatistas have not yet received an acceptable answer to their demands, which are perceived as a threat to market penetration in south-east Mexico. Business is unwilling to see the law passed, since the 'collective access to the use of natural resources in indigenous peoples' lands and territory, as proposed in the Cocopa Law, is absolutely contradictory with Article 27 of the Constitution, which protects private property as an individual guarantee"iii.

The conflict that has risen around this specific law, between private and collective ownership of property and use of natural resources, points to a broader conflict of interests, cultures and approaches to development. The Zapatista uprising thus 
highlights the roots of the conflict in Mexico, which is "...the presence of two civilisations that have neither merged to produce a new civilising project, nor coexisted harmoniously through cross-fertilisation (Bonfil, 1989:101).

In the next section, we consider the competing conceptualisations of the appropriation of nature and how these are rooted in different development paradigms.

\section{Section I - theoretical background: dominant and alternative paradigms}

The concepts under discussion in this article can be understood in the light of Marx's theory of value, which illuminates the shift from collective to private appropriation of nature. In the Mexican context, this theory can be applied to understanding the indigenous and peasant responses to market globalisation. The macroeconomic policies pursued by the government of Mexico, and the indigenous approach of integrated local development, are manifestations of different value systems; the unsustainable exploitation of the means of production versus sustainable resource management.

Moreover, natural resource use and management practices are products of a cultural context and dominant values. That is, culture shapes the symbolic meaning attributed to resources, and also people's capacity to incorporate new knowledge into the production process. This conjunction of meaning and technology has been called the socio-ecosystem (Leff 1994). In a socio-ecosystem, society manages nature to meet the needs of its members. Furtherm ore, human beings attribute values to the elements that make up their environment, thus adding a cultural dimension to the biological dynamic that determines the relationship of other living creatures with nature. These values have religious, cultural, conceptual meanings, and their multiple expression by diverse cultures has given rise to a multiplicity of perspectives on the world and human existence (Giménez 2000). In addition, they constitute symbolic systems founded on nature and determine the relational systems developed within societies for survival and reproduction (Melucci 1999).

In Mexico, national economic policies have subordinated natural resources and the rural and indigenous labour force to the requirements of industrial growth. As a result, these policies have systematically denied biological and cultural diversity: "Culture, in the sense of life style, development, rights of communities over their territories and ethnic spaces, values and traditional practices, have not been contemplated in economic paradigms" (Leff 1994). The non-recognition of indigenous cultures is not a new phenomenon. Modernisation processes over the last two centuries were shaped culturally and ideologically by a process of nationalism which, under the pretext of incorporation of minorities into the nation, sacrificed heterogeneity or cultural diversity (Boege 1998). Ironically, in the current framework of market globalisation, biodiversity and indigenous and popular forms of knowledge seem to have great potential on the world market. The trend of 
globalisation is towards a greater interest in biodiversity and people's age-old knowledge of their resources, but not in the societies that created this knowledge.

However, the globalising neo-liberal project faces a "civilising horizon" (Bonfil 1989) both cultural and territorial in nature, which constitutes an obstacle to the private appropriation of natural resources. This opposition is expressed in the different modes of socially and symbolically constructed collective and community appropriation of nature by indigenous communities, which are concentrated in the geo-economic area where the PPP is to be carried out (Toledo 1997). Today these areas, with their dense indigenous population, are seen as sources of useful resources for injecting new life into industrial society (Toledo 2000).

Indigenous and peasant communities, who own land and work it in traditional ways, are now in open rebellion, demanding recognition of their existence and their historic and cultural rights over their symbolical and material possessions. Their resistance is illustrative of the paradigm shift towards an "alternative modernity" within the world-wide debate on the type of development that should prevail in the twenty-first century (ibid). While the dominant national development paradigm is that of economic liberalisation, the prevailing paradigms in South-east Mexico have been those of eco- or sustainable development. In the framework of the social movement that emerged under the umbrella of Zapatismo, this alternative paradigm includes new concepts of autonomy (municipal or regional) that seek to integrate conservation objectives with those of development, on the basis of a recognition of the rights of indigenous communities and culture. The indigenous organisations which have come together in this movement demand social justice, recognition of diversity, construction of a new relationship with nature and transformation of the values associated with consumerism and individualism that govern the life of industrial society. These values should be replaced with ones based on solidarity and collective interest.

The Zapatista proposal brings together the concerns and demands of large sectors of the population most affected by structural adjustment policies on the road to market globalisation. Open opposition to the hegemonic and homogenising globalising project, leads to a questioning of the methods of appropriation of nature, since the demand for recognition of indigenous lands is an essential condition for the survival of indigenous people's economic, social and cultural identity.

The principles which have guided this and other environmental movements and civil society groups who advocate sustainable regional development, are rooted in a critique of the homogenisation of productive and cultural practices, and a call for values which embrace pluralism and preservation of the ethnic identities and productive practices of traditional societies (Leff 1994). Their demands call for review of the norms for economic and technological processes that, subjected to the logic of the market, have degraded the environment and quality of life. Their approach constitutes an alternative development paradigm with norms based on principles of sustainability and respect for cultural and biological diversity. Leff (ibid.) further develops this approach to argue for a set of principles and aims that would underpin 
a strategic and integrated approach to development. This paradigm, while meeting the population's basic needs and raising the quality of life, would also guarantee conservation and strengthening of the ecological basis of the natural resource system, and the prevention of disasters triggered by environmental deterioration. Access and appropriation of nature would be facilitated through means of economic decentralisation and participatory and democratic management, thus enhancing the community's right to develop their historic and cultural values, and strengthening indigenous and rural peoples' capacity for communal and technological selfdetermination. Finally, this approach would value qualitative aspects of human development above quantitative measurements of economic growth.

In the following section, we consider the differing paths or approaches to participation that are facilitated by the different paradigms discussed above, and the mechanisms through which groups excluded by the mainstream approach, can make their demands known.

\section{Section II - Paths to participation: instrumental, strategic and resistance.}

Over the last seventy years in Mexico the norm for citizen-state relations has been non-participatory or exclusionary models of governance. Even when some spaces for participation have existed, corporatist state and sectoral bargaining has combined with clientelism to mediate and control citizen participation. Public policy and strategy were devised through permanent negotiation between the corporate higher echelons of the trade unions, business and peasant leadership. A substantial mediation structure was developed where rights and the corresponding public service provision were conditioned by political-electoral loyalties along clientelist lines. Representation in these corporatist systems did not allow for alternative forms of participation, and decision-making was based on criteria such as the quotas of political and financial clout of different collective actors, their degree of militancy and their socio-economic and political importance. As a result, the interests of ruralindigenous communities were poorly represented, and they were largely excluded from participation in decision-making processes.

The recent change of regime, and new government disposition to create space for dialogue with the Zapatistas, suggests that new forms of participation are becoming possible. However, it should not be overlooked that marginalised groups are operating in an environment where economic policies of market liberalisation predominate. In such a context, three approaches to participation are possible. Firstly, participation can take the form of a negotiated integration into modernity from within the system. In this strategy, natural resources are given economic value as a way of integrating through the marketplace to globalisation. Individual rights are emphasised, in pursuit of democracy and freedom. This approach reflects local resistance to the forces of globalisation and to the disadvantageous insertion or inclusion of the periphery into globalisation, but is undertaken as part of an alternative project within the rules of the game. That is, marginalised communities 
may attempt to develop their own rules for more advantageous insertion in the existing paradigm via norms for conservation, certified ecological projects and other such initiatives.

But how can an alternative movement such as the Zapatistas secure influence over national policies? Not every social mobilisation triggers change in the spaces of participation, or spawns new types of development strategies. However, in this case we are talking about social mobilisations whose agendas are far more ambitious than those of government institutions, and whose actions challenge existing relations and express needs of a new type which can only be described as radical. Here, we make a distinction between the instrumental type of participation described above which refers to a perspective of limited citizen rights, and strategic participation, which embraces a broader perspective of citizenship that includes individual and collective rights. One of the salient characteristics of this new type of citizenship agenda is that it is not limited to establishing new forms of representation, but raises the demand for other types of participation situated in a long-term vision and capable of creating social strategies for development.

Given the perspective, time-scales and objectives of this second approach, we call this strategic participation. Strategic participation implies the articulation of processes generated through collective action, which aim to transform the rules of the game in the longer term. Given its broader perspective, this type of participation is directed at the fulfilment of social, cultural and political rights and embraces sociological, anthropological, economic and political perspectives.

Strategic participation often necessitates a strategy of outright resistance with the aim of liberation. This approach seeks spaces for the construction of liberties and autonomous spaces based on the recognition of collective rights. As such, it too embodies a counter proposal for development (an alternative paradigm) which makes demands for environmental sustainability, but also challenges the ownership of resources and promotes the principles of strategic participation and selfdetermination. In Mexico today, the forces of globalisation are met by local resistance, especially in the periphery. The cultures hidden beneath the development of mass media and market globalisation subsist in the face of globalisation and in many cases create resistance movements that demand recognition of their existence ${ }^{\mathrm{iii}}$.

Furthermore, while public policies directly or indirectly foster the private appropriation of nature, indigenous and peasant communities have resisted on the basis of their traditions and practices of community self-government and access to resources. They also maintain that their cosmogony or world vision has contributed to the conservation of the natural resources that are today concentrated in south and south-east Mexico.

Indigenous communities have combined resistance with a strategic approach to participation, whereby they demand recognition of their identity and lands, and resist exclusion from the decision-making that affects them. Furthermore, they have combined local issues of sustainable resource management with a broader discourse 
on citizenship and collective identity that resonates with the wider population. In its first public speech, in 1994, the Ejercito Zapatista de Liberación Nacional (EZLN) made clear its opposition to the North American Free Trade Agreement (NAFTA) and launched a debate that concerns not only indigenous identity and rights but also the very identity of the nation. The sympathy aroused by the Zapatista movement is a response not only to the prevailing situation of poverty, misery and exclusion suffered by large sectors of the Mexican population, but also represents the popular acknowledgement at the national level of the existence of indigenous people and their rights as part of a shared common identity and background for most Mexicans, indigenous or otherwise.

However in order for indigenous rights to be recognised, multiple strategies for participation were used, from armed struggles to a complex strategy of dialogue with civil society both nationally and internationally. This dialogue was successful in countering military offensives, but has also been crucial for the establishment of an ethical dialogue within society, that is, for indigenous peoples to enter the public sphere as a social speaker with legitimacy. Their participation has now moved from resistance to strategic, as they attempt to influence national and international environmental policies through promotion of the Cocopa law and blocking the Plan Puebla Panama.

In the following section, we attempt to draw together the theoretical debates around the appropriation of nature and approaches to participation and inclusion, and to build some potential links between participation and sustainable development.

\section{Section III - Participation and sustainable development}

Is it possible for the attempts of marginalised groups to engage strategically with the state to result in paradigm shifts towards a more sustainable development? Is there any evidence that such shifts are taking place? Where is the path to "alternative modernity", to "environmental rationality"? Alternative modernity faces the challenge of constructing itself without proposing the destruction of other existing modernities. Indeed it should propose their inclusion as a condition of its own existence. The Zapatistas express this idea in their demands for "a world where there is room for all the worlds" or "never again a Mexico without us". We find that there is a wealth of experience, writings, evidence and experiments on alternative development in Mexico. In southern Mexico especially, there is a rich experience of the sort needed to inform the design and implementation of policies for agriculture and natural resource management. These proposals are based on the alternative technologies and practices of indigenous and peasant communities (Toledo 2000, Lazos \& Paré 2000).

What is at stake in Mexico today, and the depth of conflict, is illustrated by the Cocopa Law. The acknowledgement of territorial rights in the Cocopa Law opens up the possibility for indigenous people to manage their natural resources according to their own knowledge and cultural practices. This also has implications for the 
construction of an alternative global modernity, and as an alternative development paradigm that is both inclusive and environmentally sound. What we are witnessing here is the irresolvable conflict of interests between the Zapatista communal vision and the rights recognised in the original Cocopa Law, and the national and regional vision and policies of economic liberalisation. The impasse has resulted from the Zaptistas' insistence on community control of natural resources - an option that is out of the question for the government if it is to comply with regional agreements and projects for trade liberalisation and economic integration that require free access to land for national and foreign private enterprise.

There are however, some indications of a way out of the impasse. In part, because of multiple and related crises unleashed in Mexico today. The displacement of collective forms of ownership of nature has eroded cultural diversity and the associated natural resources, creating a homogenising trend that considers nature and the rural population as disposable assets in market expansion. The use of nature (and its inhabitants) as production inputs, and the waste spewed out by industry, have unleashed an environmental crisis of enormous proportions. So much so that it threatens the very existence of the human species and now - paradoxically - this global environmental crisis presents itself as an opportunity for alternative projects of appropriation of nature.

Further, the state's non-recognition of indigenous cultures and identities has precipitated another crisis. The mestizo identity constructed over time during the construction of nationalism and the expansion of capitalism, has served as a means to consolidate the disappearance of communal forms of appropriation considered to be obstacles to market expansion. Public policies towards rural areas, the environment and the people, have been designed as the conduit for strengthening those diverse domestic and international business groups that are both the engine and beneficiary of capitalist development. Almost without exception, the logic of these policies has denied recognition of the culture and relationship that indigenous peoples and peasant communities have with the land and the environment. To paraphrase Lenin, we might say that neo-liberalism is the higher phase of imperialism, where biodiversity and peasant wisdom are products with commercial potential on world markets. However - or in direct consequence, and defying the predictions of the neo-liberal apologists who argued for a westernised global identity based on corporations and constructed by the mass media - globalisation has triggered nationalisms and the struggle for identity. Territory becomes a historical reference point and site of identities and forms of ethnic citizenship (De la Peña 1999) which mesh together to resist neo-liberal globalisation.

A further indicator of change is that the voices of different excluded groups are joining together to articulate a new, inclusive discourse for development. In Mexico, neo-zapatismo and indigenous and peasant mobilisation have reawakened the conflict of civilisations stemming from the expropriation of natural, cultural and symbolic resources. These movements have gone beyond previous indigenous struggles and succeeded (both nationally and internationally) in synthesising the demands and concerns of those social sectors excluded from globalising 
development. With a political discourse that emphasises ethics and discards the class struggle approach, neo-zapatismo erupted onto the public stage with a discourse that questions the ways in which power is exercised, and exposes the need to construct an "alternative modernity" that is inclusive, ethical and equitable.

At the same time, demands for recognition of cultural and ethnic diversity and of communal territorial rights are also opening up opportunities to increase sustainable and participatory development initiatives in many regions in southern Mexico, where there is a tremendous biological and cultural diversity. These demands could pave the way for greater influence of rural and indigenous communities and organisations in the definition and design of public policies and government programmes relating to rural affairs and natural resource management. For an alternative modernity to be constructed along principles of subsidiarity, decisionmaking must shift as near to the grassroots as possible (see Hughes, this edition). That is, where regional, national and international organisations are at the service of the local organisations and not the other way round as is the case with the current market globalisation model.

The possibilities for constructing an alternative modernity depend not only on the opening up of the political regime, but also on the capacity of civil society to organise proactively and to exert social pressure so that its proposals are taken into account within a framework of legal equity that respects and values diversity. The emergence of more inclusive concepts of citizenship rights are key in this discussion, and the adoption or rejection of the Cocopa Law by the legislature will be a crucial factor. Its rejection sabotages an opportunity for recovering the environmental and cultural capital that constitutes one of the greatest riches of any nation.

The impact of the Zapatista demands, whether they are successful or not, will be decisive in public policy on natural resources and biodiversity. Success could mean a new stage in the relationship that Mexican society has as a whole with its environmental capital. Failure could undermine resistance and open wide the door to the indiscriminate incorporation of natural resources and indigenous knowledge into the market, without the participation of their traditional owners.

\section{References}

Boege, E. (1998), 'Los mazatecos ante la nación: Contradicciones de la identidad étnica en el México Actual'. Mexico City: Siglo XXI.

Bonfil Batalla, G. (1989), 'México Profundo: Una Civilización Negada', Mexico: Grijalbo, Consejo Nacional para la Cultura y las Artes.

De la Peña, G. (1999), 'Territorio y ciudadanía étnica en la nación globalizada'. In: Desacatos, Revista de Antropología, No. 1 Primavera 1999 pp. $13-27$ 
Giménez, G. (2000) 'Territorio, cultura e identidades: La región socio - cultural' in Globalización y regiones en México, González Ortega, R. (ed.). Mexico: Faculty of Political and Social Sciences, UNAM; pp. 19-52.

Lazos and Paré, L. (2000). "Miradas indígenas sobre una naturaleza entristecida. Percepciones ambientales entre los nahuas del Golfo de México", Mexico: Plaza y Valdes-UNAM

Leff, E. (1994) 'Ecología y Capital: racionalidad ambiental, democracia participativa desarrollo sustentable', Mexico: Siglo XXI Editores, UNAM.

Melucci, A. (1999) 'Esfera pública y democracia en la era de la información' Metapolítica. Vol.3, No. 9, pp. $57-67$.

Toledo, V. M. (1997) 'La utopía realizándose: el desarrollo sustentable de comunidades y ejidos', in Ojarasca núm. 4, agosto de 1997. Supplement of the newspaper La Jornada.

Toledo, V. M. (2000) 'La paz en Chiapas. Ecología, luchas indígenas y modernidad alternativa', Mexico City: Quinto Sol, Instituto de Ecología, UNAM.

\footnotetext{
${ }^{\mathrm{i}}$ La Jornada 2 January 2001. Note by Carlos Fazio.

ii La Jornada newspaper, 28th March 2001, note by David Zúñiga.

iii To a great extent, the territorial omnipresence of particular methods of social organisation has led to the need to legislate as is the case where indigenous "uses and customs" are accepted in the electoral laws of Oaxaca state. In this way the indigenous communities can continue to elect their authorities according to their custom.
} 